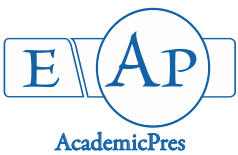

Ezeh GC et al. (2021)

Notulae Scientia Biologicae

Volume 13, Issue 2, Article number 10939

DOI: $10.15835 / \mathrm{nsb} 13210939$

Research Article

\title{
Acute and sub-acute toxicity profile of methanol extract of Hura crepitans leaf on Wistar rats
}

\author{
Gladys C. EZEH ${ }^{1}$, Nkeiruka E. UDEH ${ }^{2}$, Christian A. OZIOKO ${ }^{3}$, \\ Samuel O. ONOJA ${ }^{4 *}$, Raphael E. EZE ${ }^{5}$, Yusuf N. OMEH ${ }^{5}$, \\ Maxwell I. EZEJA ${ }^{4}$, Aruh O. ANAGA ${ }^{6}$
${ }^{1}$ Alex Ekwueme Federal University, Department of Agriculture, Ndufu Alike-Ikwo, Ebonyi State, Nigeria; joanezeh1@gmail.com
${ }^{2}$ Michael Okpara University of Agriculture, Department of Veterinary Biochemistry and Animal Health in Production, Umudike,PMB 7267, Abia State, Nigeria; udeh.nkeiruka@mouau.edu.ng
${ }^{3}$ Michael Okpara University of Agriculture, Department of Veterinary Microbiology, Umudike, PMB 7267, Abia State, Nigeria; christiananene333@gmail.com
${ }^{4}$ Michael Okpara University of Agriculture, Department of Veterinary Physiology and Pharmacology, Umudike, PMB 7267, Abia State,Nigeria; onoja.samuel@mouau.edu.ng; samonreal@yahoo.com; maxwell.ezeja@gmail.com (*correspondingauthor) ${ }^{5}$ Michael Okpara University of Agriculture, Department of Biochemistry, Umudike, PMB 7267, AbiaState,Nigeria; ralphaeleze@yahoo.com;nduk41@yahoo.com
${ }^{6}$ University of Nigeria, Department of Veterinary Physiology and Pharmacology, Nsukka, Nigeria; aruh.anaga@unn.edu.ng

\begin{abstract}
This study investigated the toxicity profile of methanol extract of Hura crepitans leaf on albino rats. The up-and-down method at a dose limit of $2000 \mathrm{mg} / \mathrm{kg}$ was used in the oral acute toxicity test. Twenty-four (24) albino Wistar rats were randomly assigned to 4 groups $(A-D, n=6)$. Group A (control) received distilled water, while groups B-D received 100, 200 and $400 \mathrm{mg} / \mathrm{kg}$ of the extract, respectively. The rats were dosed once daily for 21 consecutive days and weighed weekly. Twenty-four hours after the last treatment on day 21 , the rats were fasted overnight and blood was collected into EDTA and plain bottles for hematological evaluation and serum preparation respectively. A manual method was used to determine the full blood cell count, while Randox kit was used to estimate the serum markers of liver and kidney functions. The extract was tolerated by the rat; the $\mathrm{LD}_{50}$ was greater than $2000 \mathrm{mg} / \mathrm{kg}$. At 21 days of treatment, the extract $(100,200$ and $400 \mathrm{mg} / \mathrm{kg})$ treated groups had $27.53,25.98$ and $25.33 \%$ weight gain respectively, while the distilled water treated group had $8.38 \%$ weight gain. The extract $(200$ and $400 \mathrm{mg} / \mathrm{kg})$ reduced $(\mathrm{p}<0.05)$ the packed cell volume, hemoglobin concentration and red cell count, serum aspartate aminotransferase, alanine aminotransferase and alkaline phosphatase activities, but increased the total white blood cell in the treated groups when compared with the control group. This study suggests that methanol extract of Hura crepitans has hepatoprotective activity, promotes weight gain and could precipitate anemia when taken for a long period.
\end{abstract}

Keywords: hematology; Hura crepitans; hepatoprotective; toxicity; weight gain

Received: 01 Apr 2021. Received in revised form: 23 Apr 2021. Accepted: 11 May 2021. Published online: 14 May 2021.

From Volume 13, Issue 1, 2021, Notulae Scientia Biologicae journal uses article numbers in place of the traditional method of continuous pagination through the volume. The journal will continue to appear quarterly, as before, with four annual numbers. 


\section{Introduction}

There is a growing interest in the use of herbal preparations in the management of disease conditions. About $80 \%$ of the world populace have used herbal preparation either as a supplement or a therapeutic agent (Ezuruike and Prieto, 2014; Onoja et al., 2018). Herbal preparations are perceived to be devoid of side effects, but this is not true especially when used for a prolonged time (Kunle et al., 2012; Ezeja et al., 2014). Despite the soaring interest in herbal preparation, it is rarely or not prescribed by orthodox medical personnel and this could be due to the possibility of toxicity or incompatibility/interaction with other medications. Considering this, World Health Organization has recommended the safety assessment of herbal preparation (Jordan et al., 2010).

Hura crepitans is a member of the family Euphorbiaceae and commonly known as "Sandbox tree", "possumwood", "monkey's dinner bell" and "monkey's pistol". It is a tree that grows up to 40 meters high. It is native to tropical America and presently found in tropical rainforest regions. It is recognized by many dark, pointed (conical) spines and papery thin, heart-shaped leaves (Oloyede et al., 2016; Owojuyigbe et al., 2020). In ethnomedicinal practices, the plant is used as an emetic, purgative, antimicrobial, anti-inflammatory and in the management of leprosy (Oloyede and Olatinwo, 2011). The latex is used as an arrow poison, while the milky sap is poisonous to fish, due to the presence of huratoxine and hexahydrohuratoxin, which causes hemagglutination and inhibits protein synthesis (Vassallo et al., 2020). Phytochemical evaluations have revealed the presence of alkaloids, tannins, saponins, phytate, oxalate, cyanide and trypsin in the seed, leaf and stem-bark of $H$. crepitans (Fowomola and Akindahunsi, 2007; Vassallo et al., 2020). The in vitro cytotoxic and anti-viral effects of daphnanes diterpenes (huratoxin, 2,3-dihydrohuratoxin, $6^{\prime}$-oxohuratoxin, prohuratoxin, and stelleralide J) isolated the latex of Hura crepitans have been reported (Trinel et al., 2020), but there is a dearth of information on the in vivo toxicity profile of $H$. crepitans despite its use for a prolonged period in ethnomedicine. Hence, this study was designed to investigate the in vivo hepatic, hematological and nephrological toxicity profiles of $H$. crepitans in Wistar rats.

\section{Materials and Methods}

\section{Plant identification/collection}

Fresh leaves of Hura crepitans were obtained from Michael University of Agriculture Umudike environment in June, 2017 and authenticated by a taxonomist, Prof. Michael C. Dike. A voucher specimen (MOUAU/CVM/VPP/2017/4) was kept in the departmental herbarium for reference.

\section{Extract preparation}

The leaves were washed and air-dried to constant weight and then pulverized into a coarse powder using an electric hammer mill (Jiangxi, China). The pulverized leaf was macerated in $80 \%$ methanol (JHD, China) for $48 \mathrm{~h}$. The filtrate obtained was concentrated in vacuo using a rotary evaporator (Cole-Parmer type N-1110, China). The Hura crepitans extract (HCE) was preserved at $4{ }^{\circ} \mathrm{C}$.

\section{Experimental animal}

Twenty-four (24) albino Wistar rats of both sexes were used for the study. The animals were housed in wire-mesh cages, fed ad libitum with pelleted feed (Vital Feed', Nigeria) and water except when fasting was required. The experimental protocol was approved by the Institutional Animal Ethics Committee. The animals were handled regarding the Guide for the Care and Use of Laboratory Animals of the National Research Council (National Research Council, 2010). 
Acute toxicity test

The acute toxicity test of HCE was conducted using the "Up and Down" method at a limit dose of 2000 $\mathrm{mg} / \mathrm{kg}$ in rats (OECD, 2008).

\section{Experimental design}

Twenty-four (24) rats were randomly assigned to four groups (A-D, $n=6$ ). Group A received distilled water $5 \mathrm{ml} / \mathrm{kg}$, while groups B-D received HCE 100, 200 and $400 \mathrm{mg} / \mathrm{kg}$, respectively. The rats were dosed once daily for 3 weeks via oral gavage. The weight was taken on day zero, 7, 14 and 21 . After the last treatment on week 3 , the rats fasted for $16 \mathrm{~h}$ and the blood sample was collected afterward (into plain and EDTA sample bottles). Thereafter, the rats were sacrificed and the visceral organs (liver, kidney, spleen, and heart) were excised after laparotomy for the determination of organosomatic indices. The percentage weight gain was calculated as follows:

$\%$ weight gain $=\frac{\text { weight } B-\text { weight } A}{\text { Weight } A} \times \frac{100}{1}$

Where: Weight $A=$ weight on week zero, while weight $B=$ weight on days 7,14 or 21 .

Organosomatic index $=\frac{\text { weight of organ }}{\text { body weight of animal }} \times \frac{100}{1}$

\section{Hematological analysis}

The red blood cell (RBC), platelet and white blood cell (WBC) count, packed cell volume (PCV) and hemoglobin $(\mathrm{HB})$ concentration, mean corpuscular volume (MCV), mean corpuscular hemoglobin $(\mathrm{MCH})$ and mean corpuscular hemoglobin concentration $(\mathrm{MCHC})$ were determined using automated hematology analyzer (OX-360, Balio diagnostics, France).

\section{Determination of biochemical parameters}

Alanine aminotransferase (ALT), aspartate aminotransferase (AST), alkaline phosphatase (ALP), total protein, albumin, bilirubin (total and direct), urea and creatinine levels were determined in the serum using a commercially available Randox reagent kit (Randox Diagnostics, UK).

\section{Statistical analysis}

Data obtained were presented as mean \pm SEM and analysed using one-way-analysis of variance (ANOVA) and posthoc comparisons were carried out using Dunnett's t-test on SPSS version 20. Values of $\mathrm{p}$ $<0.05$ were considered significant in the study.

\section{Results}

\section{Acute toxicity test}

No signs of toxicity and death were recorded in the treated rats. The $\mathrm{LD}_{50}$ was greater than $2000 \mathrm{mg} / \mathrm{kg}$. The extract is relatively safe for consumption.

\section{Effects of HCE on percentage body weight gain of treated rats}

The HCE produced a significant $(\mathrm{p}<0.05)$ time-dependent (but not dose-dependent) increase in weight gain in the treated rats when compared with the rats in the distilled water treated group (Table 1). At 21 days of treatment, the HCE 100, 200 and $400 \mathrm{mg} / \mathrm{kg}$ treated groups had 27.53, 25.98 and $25.33 \%$ weight gain, while the distilled water treated group had $8.38 \%$ weight gain. 


\section{Effects of HCE on organosomatic indices of treated rats}

There was no significant $(\mathrm{p}>0.05)$ change in the organosomatic indices of the HCE-treated groups when compared with the distilled water-treated group (Table 2).

\section{Effects of HCE on hematological parameters of treated rats}

The HB, RBC and PCV levels of the HCE-treated groups were significantly $(\mathrm{p}<0.05)$ reduced when compared with the distilled water treated group (Table 3). There was no significant $(p>0.05)$ difference in the WBC and platelet counts as well as MCV, MCH, and MCHC levels of HCE-treated groups when compared with the distilled water treated group.

Table 1. Effects of HCE on percentage body weight gain of treated rats

\begin{tabular}{|l|c|c|c|c|}
\hline \multirow{2}{*}{ Duration (day) } & \multicolumn{4}{|c|}{ Weight gain (\%) } \\
\cline { 2 - 5 } & $\begin{array}{c}\text { Distilled water } \\
5 \mathrm{mg} / \mathrm{kg}\end{array}$ & $\begin{array}{c}\mathrm{HCE} \\
100 \mathrm{mg} / \mathrm{kg}\end{array}$ & $\begin{array}{c}\mathrm{HCE} \\
200 \mathrm{mg} / \mathrm{kg}\end{array}$ & $\begin{array}{c}\text { HCE } \\
400 \mathrm{mg} / \mathrm{kg}\end{array}$ \\
\hline 7 & $-0.08 \pm 1.29$ & $-0.62 \pm 1.05$ & $1.56 \pm 0.65$ & $1.08 \pm 0.34$ \\
\hline 14 & $7.78 \pm 1.98$ & $17.60 \pm 2.45^{*}$ & $16.38 \pm 2.02^{*}$ & $14.49 \pm 2.21^{*}$ \\
\hline $21{ }^{*} \mathrm{p}<0.05$ when compared with the distilled water treated group, HCE $=$ Hura crepitans extract & $25.33 \pm 3.94^{*}$ \\
\hline
\end{tabular}

Table 2. Effects of HCE on organosomatic indices of treated rats

\begin{tabular}{|l|c|c|c|c|}
\hline \multicolumn{1}{|c|}{ Organs } & $\begin{array}{c}\text { Distilled water } \\
5 \mathrm{mg} / \mathrm{kg}\end{array}$ & $\begin{array}{c}\mathrm{HCE} \\
100 \mathrm{mg} / \mathrm{kg}\end{array}$ & $\begin{array}{c}\text { HCE } \\
200 \mathrm{mg} / \mathrm{kg}\end{array}$ & $\begin{array}{c}\text { HCE } \\
\mathbf{4 0 0} \mathrm{mg} / \mathrm{kg}\end{array}$ \\
\hline Kidney & $0.72 \pm 0.04$ & $0.68 \pm 0.04$ & $0.71 \pm 0.01$ & $0.61 \pm 0.03$ \\
\hline Liver & $3.31 \pm 0.10$ & $3.53 \pm 0.13$ & $3.77 \pm 0.17$ & $3.46 \pm 0.12$ \\
\hline Heart & $0.37 \pm 0.03$ & $0.43 \pm 0.04$ & $0.43 \pm 0.02$ & $0.43 \pm 0.05$ \\
\hline Spleen & $0.43 \pm 0.02$ & $0.58 \pm 0.14$ & $0.58 \pm 0.14$ & $0.52 \pm 0.05$ \\
\hline
\end{tabular}

${ }^{*} \mathrm{p}<0.05$ when compared with the distilled water treated group, HCE $=$ Hura crepitans extract

Table 3. Effects of HCE on hematological parameters of treated rats

\begin{tabular}{|l|c|c|c|c|}
\hline \multicolumn{1}{|c|}{ Parameters } & $\begin{array}{c}\text { Distilled water } \\
5 \mathrm{mg} / \mathrm{kg}\end{array}$ & $\begin{array}{c}\text { HCE } \\
100 \mathrm{mg} / \mathrm{kg}\end{array}$ & $\begin{array}{c}\text { HCE } \\
200 \mathrm{mg} / \mathrm{kg}\end{array}$ & $\begin{array}{c}\text { HCE } \\
400 \mathrm{mg} / \mathrm{kg}\end{array}$ \\
\hline $\mathrm{WBC}\left(\mathrm{x} 10^{3} / \mu \mathrm{l}\right)$ & $16.10 \pm 2.45$ & $14.17 \pm 1.91$ & $19.13 \pm 3.80$ & $20.50 \pm 1.07$ \\
\hline $\mathrm{HB}(\mathrm{g} / \mathrm{dL})$ & $15.23 \pm 0.61$ & $13.97 \pm 0.54$ & $12.47 \pm 0.29^{*}$ & $12.27 \pm 0.15^{*}$ \\
\hline $\mathrm{RBC}\left(\mathrm{x} 10^{6} / \mu \mathrm{l}\right)$ & $8.29 \pm 0.33$ & $7.51 \pm 0.22$ & $6.93 \pm 0.24^{*}$ & $6.54 \pm 0.28^{*}$ \\
\hline $\mathrm{PCV}(\%)$ & $56.13 \pm 2.80$ & $52.30 \pm 1.51$ & $47.47 \pm 1.18^{*}$ & $46.37 \pm 0.22^{*}$ \\
\hline $\mathrm{MCV}(\mathrm{Fl})$ & $67.73 \pm 0.98$ & $69.70 \pm 1.17$ & $67.40 \pm 0.26$ & $68.07 \pm 0.18$ \\
\hline $\mathrm{MCH}(\mathrm{Pg})$ & $18.37 \pm 0.13$ & $18.53 \pm 0.26$ & $17.70 \pm 0.06$ & $17.53 \pm 0.29$ \\
\hline $\mathrm{MCHC}(\mathrm{g} / \mathrm{L})$ & $271.33 \pm 5.55$ & $266.67 \pm 7.80$ & $264.00 \pm 1.53$ & $262.00 \pm 2.00$ \\
\hline Platelet $\left(\mathrm{x} 10^{3} / \mu \mathrm{l}\right)$ & $647.67 \pm 16.33$ & $621.33 \pm 110.48$ & $670.00 \pm 45.09$ & $624.67 \pm 10.17$ \\
\hline
\end{tabular}

${ }^{*} \mathrm{p}<0.05$ when compared with the distilled water treated group, $\mathrm{HCE}=$ Hura crepitans extract, RBC $=$ red blood cell, $\mathrm{WBC}=$ white blood cell, $\mathrm{PCV}=$ packed cell volume, $\mathrm{HB}=$ hemoglobin, $\mathrm{MCV}=$ mean corpuscular volume, $\mathrm{MCH}=$ mean corpuscular hemoglobin, $\mathrm{MCHC}=$ mean corpuscular hemoglobin concentration

\section{Effects of HCE on serum biochemical parameters of treated rats}

The effects of HCE on the serum biochemical parameters of treated Wistar rats are presented in Table 4. The serum AST activities of HCE $(200$ and $400 \mathrm{mg} / \mathrm{kg})$ treated groups were significantly $(\mathrm{p}<0.05)$ diminished when compared with the distilled water treated group. The serum ALP and ALT activities of HCE 100 and $200 \mathrm{mg} / \mathrm{kg}$ treated groups respectively, were significantly reduced when compared with the distilled water treated group. The serum total and direct bilirubin levels of HCE-treated groups were significantly $(\mathrm{p}<$ $0.05)$ reduced when compared with the distilled water treated group. 
Table 4. Effects of HCE on serum biochemical parameters of treated rats

\begin{tabular}{|l|c|c|c|c|}
\hline \multicolumn{1}{|c|}{ Parameters } & $\begin{array}{c}\text { Distilled water } \\
5 \mathrm{mg} / \mathrm{kg}\end{array}$ & $\begin{array}{c}\text { HCE } \\
100 \mathrm{mg} / \mathrm{kg}\end{array}$ & $\begin{array}{c}\text { HCE } \\
200 \mathrm{mg} / \mathrm{kg}\end{array}$ & $\begin{array}{c}\text { HCE } \\
400 \mathrm{mg} / \mathrm{kg}\end{array}$ \\
\hline AST $(\mathrm{IU} / \mathrm{L})$ & $81.25 \pm 8.36$ & $81.43 \pm 7.58$ & $63.63 \pm 4.34^{*}$ & $56.03 \pm 5.83^{*}$ \\
\hline ALT $(\mathrm{IU} / \mathrm{L})$ & $15.68 \pm 2.56$ & $13.25 \pm 1.33$ & $14.45 \pm 1.60$ & $8.40 \pm 0.24^{*}$ \\
\hline ALP $(\mathrm{IU} / \mathrm{L})$ & $36.96 \pm 4.49$ & $23.04 \pm 2.29^{*}$ & $29.46 \pm 1.06$ & $28.25 \pm 2.58$ \\
\hline TP $(\mathrm{g} / \mathrm{dL})$ & $7.27 \pm 0.25$ & $7.04 \pm 0.24$ & $6.69 \pm 0.11$ & $6.65 \pm 0.63$ \\
\hline ALB $(\mathrm{g} / \mathrm{dL})$ & $3.53 \pm 0.42$ & $3.82 \pm 0.10$ & $3.90 \pm 0.11$ & $3.68 \pm 0.06$ \\
\hline GLB $(\mathrm{g} / \mathrm{dL})$ & $3.73 \pm 0.24$ & $3.22 \pm 0.29$ & $2.80 \pm 0.16$ & $2.97 \pm 0.66$ \\
\hline TBIL $(\mathrm{mg} / \mathrm{dL})$ & $0.20 \pm 0.02$ & $0.09 \pm 0.01^{*}$ & $0.08 \pm 0.00^{*}$ & $0.10 \pm 0.00^{*}$ \\
\hline DBIL $(\mathrm{mg} / \mathrm{dL})$ & $0.17 \pm 0.00$ & $0.06 \pm 0.00^{*}$ & $0.05 \pm 0.01^{*}$ & $0.05 \pm 0.00^{*}$ \\
\hline Creatinine $(\mathrm{mg} / \mathrm{dL})$ & $0.96 \pm 0.04$ & $0.78 \pm 0.09$ & $0.82 \pm 0.03$ & $0.86 \pm 0.03$ \\
\hline Urea $(\mathrm{mg} / \mathrm{dL})$ & $32.15 \pm 1.36$ & $37.65 \pm 1.12$ & $29.70 \pm 4.95$ & $35.59 \pm 3.36$ \\
\hline
\end{tabular}

${ }^{*} \mathrm{p}<0.05$ when compared with the distilled water treated group, HCE $=$ Hura crepitans extract, ALT $=$ alanine aminotransferase, $\mathrm{AST}=$ aspartate aminotransferase, $\mathrm{ALP}=$ alkaline phosphatase, $\mathrm{TP}=$ total protein, $\mathrm{ALB}=$ albumin, TBIL = total bilirubin, $\mathrm{DBIL}=$ direct bilirubin

\section{Discussion}

This study assessed the acute and sub-acute toxicity profile of the methanol extract of Hura crepitans leaf in Wistar rats. The $\mathrm{LD}_{50}$ of the extract was greater than $2000 \mathrm{mg} / \mathrm{kg}$. The sub-acute treatment of HCE produced significant $(\mathrm{p}<0.05)$ weight gain, caused anemia and hepatoprotective effects in the treated rats. The aforementioned effects could be linked to the phytoconstituents of $H$. crepitansleaf. The presence of alkaloids, tannins, saponins and flavonoids in the leaf of $H$. crepitans have been reported (Fowomola and Akindahunsi, 2007; Vassallo et al., 2020).

A single dose of HCE $(2000 \mathrm{mg} / \mathrm{kg})$ was well tolerated as no signs of morbidity or mortality were recorded. The LD50 was greater than $2000 \mathrm{mg} / \mathrm{kg}$, thus the extract can be adjudged to be relatively safe (OECD, 2008).

The HCE-treated groups had more $(\mathrm{p}<0.05)$ accelerated weight gain when compared with the distilled water-treated group. This could be due to micronutrients and phytochemicals present in the HCE, which may have improved feed conversion efficiency and enhanced the growth (Fowomola and Akindahunsi, 2007; Vassallo et al., 2020). The organosomatic index showed no significant change in all the organs (livers, kidneys, hearts, and spleens) examined. This indicates that there was no noticeable deleterious effect on these organs as elevated organosomatic index indicates pronounced organ degeneration (Singh et al., 2007).

The HCE (200 and $400 \mathrm{mg} / \mathrm{kg}$ ) caused normocytic and normochromic anemia in the treated rats that could be linked to the phytoconstituents. H. crepitans is rich in saponins which are known to induce eryptosis and hemolysis of red blood cells (Bissinger et al., 2014; Fowomola and Akindahunsi, 2007; Waheed et al., 2012). Saponins stimulate cell membrane scrambling via increased cytosolic calcium ion $\left(\mathrm{Ca}^{2+}\right)$ activity and ceramide formation at the surface of RBC, which predispose the cell to eryptosis (Bissinger et al., 2014; Lang et al., 2012). The stimulation of eryptosis is followed by the removal of the damaged RBC before hemolysis. Enhanced eryptosis is associated with anemia (Lupescu et al., 2015). Saponins-induced hemolysis occurs as a result of cell membrane leakage due to net uptake of sodium ion $\left(\mathrm{Na}^{+}\right)$and chloride ion $(\mathrm{Cl})$ and associated cell swelling, which causes the rupture of RBC (Bissinger et al., 2014; Lang et al., 2012). Enhanced hemolysis also leads to anemia (Bissinger et al., 2019).

The biochemical findings indicate that the kidney was not negatively impacted despite the possible saponins-induced hemolysis. This is because eryptosis precedes hemolysis and prevented the massive release of hemoglobin that would have occluded the renal tubule and predispose to nephropathy (Lang et al., 2012). 
Elevated serum urea and creatinine levels indicate nephropathy. But in this study, the serum urea and creatinine level did not vary significantly $(\mathrm{p}>0.05)$ when compared with the control group.

The biochemical findings also suggest that HCE did not produce deleterious effects on the liver, rather it elicited hepatoprotective properties. It reduced the ALT, AST and ALP activities as well as diminished bilirubin levels in the treated rats when compared to the control group. This is in agreement with the report of previous studies on the hepatoprotective potential of $H$. crepitans leaf (Owojuyigbe et al., 2020a). The polar extracts of $H$. crepitansleaf have been shown to possess polyphenols with validated hepatoprotective properties (Vassallo et al., 2020). The hepatoprotective potentials of polyphenols are linked to their antioxidant property. Antioxidants mop up free radicals, inhibit lipid peroxidation and enhance membrane integrity. The antioxidant potential of $H$. crepitans has been documented (Owojuyigbe et al., 2020b).

\section{Conclusions}

In conclusion, this study suggests that methanol extract of Hura crepitans is relatively safe, has hepatoprotective activity, promotes weight gain and could precipitate anaemia when taken for a long period.

\section{Authors' Contributions}

GCE, NEU and SOO were involved in the conceptualization, design, execution, draft and review of the manuscript; CAO and REE participated in the design, sourcing of material, statistical analysis and review of manuscript while YNO, AOA and MIE were involved in the supervision, review and editing of the manuscript. All the authors read and approved the final manuscript.

All authors read and approved the final manuscript.

\section{Ethical approval}

The experimental protocol was approved by the institutional Animal Ethics Committee of the College of Veterinary Medicine, Michael Okpara University of Agriculture Umudike.

\section{Acknowledgements}

The authors are grateful to Prof. Michael C. Dike for the identification of the plant sample.

\section{Conflict of Interests}

The authors declare that there are no conflicts of interest related to this article.

\section{References}

Adindu EA, Elekwa I, Ogwo JI (2016). Phytochemical comparative screening of aqueous extracts of the leaves, stem barks, and roots of Hura crepitans (L) using GC-FID. IOSR Journal of Biotechnology and Biochemistry 2(1):24552463. https://www.iosrjournals.org/iosr-jbb/papers/Vol2-issue1/C0211118.pdf 
Bissinger R, Bhuyan AA, Qadri SM, Lang F (2019). Oxidative stress, eryptosis and anemia: a pivotal mechanistic nexus in systemic diseases. The FEBS Journal 2286(5):826-854. https://doi.org/10.1111/febs. 14606

Bissinger R, Modicano P, Alzoubi K, Honisch S, Faggio C, Abed M, Lang F (2014). Effect of saponin on erythrocytes. International Journal of Hematology 100(1):51-59. https://doi.org/10.1007/s12185-014-1605-Z

Ezeja MI, Anaga AO, Asuzu IU (2014). Acute and sub-chronic toxicity profile of methanol leaf extract of Gouania longipetala in rats. Journal of Ethnopharmacology 151(3):1155-1164. https://doi.org/10.1016/j.jep.2013.12.034

Ezuruike UF, Prieto JM (2014). The use of plants in the traditional management of diabetes in Nigeria: Pharmacological and toxicological considerations. Journal of Ethnopharmacology 155(2):857-924. https://doi.org/10.1016/j.jep.2014.05.055

Fowomola MA, Akindahunsi AA (2007). Nutritional quality of sandbox tree (Hura crepitans Linn.). Journal of Medicinal Food 10(1):159-64. https://doi.org/10.1089/jmf.2005.062

Jordan SA, Cunningham DG, Marles RJ (2010). Assessment of herbal medicinal products: challenges, and opportunities to increase the knowledge base for safety assessment. Toxicology and Applied Pharmacology 243(2):198-216. https://doi.org/10.1016/j.taap.2009.12.005

Kunle OF, Egharevba HO, Ahmadu PO (2012). Standardization of herbal medicines-A review. International Journal of Biodiversity and Conservation 4(3):101-112. https://doi.org/10.5897/IJBC11.163

Lang E, Qadri SM, Lang F (2012). Killing me softly-suicidal erythrocyte death. The International Journal of Biochemistry and Cell Biology 44(8):1236-1243. https://doi.org/10.1016/j.biocel.2012.04.019

Lupescu A, Bissinger R, Goebel T, Salker MS, Alzoubi K, Liu G, ... Lang F (2015). Enhanced suicidal erythrocyte death contributing to anemia in the elderly. Cellular Physiology and Biochemistry 36(2):773-783. https://doi.org/10.1159/000430137

National Research Council (2010). Guide for the care and use of laboratory animals. National Academies Press, http://www.nap.edu/catalog/12910.html

OECD (2008). Guidelines for the testing of chemicals, acute oral toxicity - up-and down - procedure, no. 425. https://www.oecd-ilibrary.org

Oloyede GK and Olatinwo MB (2011). In vitro antioxidant activity of extracts from the leaves of Hura crepitans (Euphorbiaceae)-a comparison of two assay methods. Cell Membranes and Free Radical Research 3(1):133-138. https://dergipark.org.tr/en/pub/sducmfrr/issue/20745/221715

Oloyede GK, Adaramoye OA, Olatinwo MB (2016). Chemical constituents of sandbox tree (Hura crepitans Linn.) and anti hepatoxic activity of leaves and stem bark extracts. West Indian Medical Journal. https://doi.org/10.7727/wimj.2015.247

Onoja SO, Udem SC, Anaga AO, Asuzu IU (2018). Acute and chronic toxicity studies of hydromethanol leaf extract of Helianthus annuus Linn. in rats. Asian Pacific Journal of Tropical Medicine 11(9):534-539. https://doi.org/10.4103/1995-7645.242311

Owojuyigbe OS, Firempong CK, Komlaga G, Larbie C, Emikpe BO (2020b). Phytochemical, antioxidant and safety evaluation of Hura crepitans (L.) stem bark hydroethanolic extract in animals. European Journal of Medicinal Plants 31(8):1-6. https://doi.org/10.9734/EJMP/2020/v31i830255

Owojuyigbe OS, Firempong CK, Larbie C, Komlaga G, Emikpe BO (2020a). Hepatoprotective potential of Hura crepitans L.: A review of ethnomedical, phytochemical and pharmacological studies. Journal of Complementary and Alternative Medical Research 9(2):1-10. https://doi.org/10.9734/jocamr/2020/v9i230136

Singh ND, Sharma AK, Dwivedi P, Patil RD, Kumar M (2007). Citrinin and endosulfan induced maternal toxicity in pregnant Wistar rats: pathomorphological study. Journal of Applied Toxicology 27(6): 589-601. https://doi.org/10.1002/jat.1242

Trinel M, Le Lamer AC, Jullian V, Jacquemin D, Graton J, Cristofoli V, ... Mejia K (2020). Daphnanes diterpenes from the latex of Hura crepitans L. And activity against human colorectal cancer cells Caco-2. Bioorganic Chemistry 103:104132. https://doi.org/10.1016/j.bioorg.2020.104132

Vassallo A, Armentano MF, Miglionico R, Caddeo C, Chirollo C, Gualtieri MJ, ... Milella L (2020). Hura crepitans L. extract: phytochemical characterization, antioxidant activity, and nanoformulation. Pharmaceutics 12(6):553. https://doi.org/10.3390/pharmaceutics 12060553

Waheed A, Barker J, Barton SJ, Owen CP, Ahmed S, Carew MA (2012). A novel steroidal saponin glycoside from Fagonia indica induces cell-selective apoptosis or necrosis in cancer cells. European Journal of Pharmaceutical Sciences 47:464-473. https://doi.org/10.1016/j.ejps.2012.07.004 
Ezeh GC et al. (2021). Not Sci Biol 13(2):10939

OPEN ACCESS

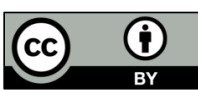

The journal offers free, immediate, and unrestricted access to peer-reviewed research and scholarly work. Users are allowed to read, download, copy, distribute, print, search, or link to the full texts of the articles, or use them for any other lawful purpose, without asking prior permission from the publisher or the author.

License - Articles published in Notulae Scientia Biologicae are Open-Access, distributed under the terms and conditions of the Creative Commons Attribution (CC BY 4.0) License.

(c) Articles by the authors; SHST, Cluj-Napoca, Romania. The journal allows the author(s) to hold the copyright/to retain publishing rights without restriction. 